[Chem. Pharm. Bull.

36(11)4275-4283(1988)

\title{
Structural Elucidation of Triptofordins F-1, F-2, F-3, and F-4, New Sesquiterpenes Polyesters from Tripterygium wilfordii HOOK fil. var. regelii MAKINO
}

\author{
Yoshihisa TaKaishi, * Kunie Ujita, Kimiko NaKano, \\ and Toshiaki Tomimatsu \\ Faculty of Pharmaceutical Sciences, The University of Tokushima, \\ Shomachi, Tokushima 770, Japan
}

(Received March 26, 1988)

\begin{abstract}
New sesquiterpene esters designated triptofordins F-1 (1), F-2 (7), F-3 (10), and F-4 (5) were isolated from the leaves of Tripterygium wilfordii HoOK fil. var. regelii MAKINO. Their structures were established by spectroscopic investigation and chemical reactions. The absolute structures of these compounds were determined by using the dibenzoate chirality method.
\end{abstract}

Keywords_-Tripterygium wilfordii; Celastraceae; triptofordin; sesquiterpene; dibenzoate chirality method

Tripterygium wilfordii HOOK has been used as an anticancer drug and as an insecticide by the Chinese for hundreds of years. Recently, this plant has been used to treat rheumatoid arthritis and spondylitis in some Chinese clinics. ${ }^{1)}$ The active antileukemic principles, triptolide and tripdiolide were isolated from this plant by Kupchan et al. ${ }^{2)}$ Kutney et al. reported the production of triptolide and tripdiolide by tissue cultures of this plant. ${ }^{3)}$ The alkaloid contents of this plant were also reported ${ }^{4}{ }^{4}$ Certain triterpenoids and sesquiterpenes were recently isolated from the roots of $T$. wilfordii, ${ }^{5)}$ but information on its chemistry is limited to the root bark. We have been studying the sesquiterpene constituents of $T$. wilfordii HOOK fil. var. regelii MAKINO. Recently we have described the isolation and structural determination of seven new (triptofordins A, B, C-1, C-2, D-1, D-2, and E) and two known dihydroagarofuran sesquiterpenes from the leaves of this plant. ${ }^{6}{ }^{6}$ One of these sesquiterpenes is known to be the active principle against the larval stages of Strongyloides stercoralis and hookworms. ${ }^{17)}$

The crude extract was further chromatographed to isolate four new sesquiterpenes. The structural elucidation of these four new sesquiterpenés, triptofordins F-1 (1), F-2 (7), F-3 (10), and F-4 (5), is described here.

Triptofordin F-1 (1) showed absorptions at $3450(\mathrm{OH}), 1740$, and $1712(\mathrm{COO}) \mathrm{cm}^{-1}$ in the infrared (IR) spectrum. The ultraviolet (UV) spectrum of 1 showed the presence of aromatic rings. The presence of acetate, benzoate and cinnamate ester groups in $\mathbf{1}$ was revealed by the proton and carbon 13 nuclear magnetic resonance $\left({ }^{1} \mathrm{H}-\right.$ and $\left.{ }^{13} \mathrm{C}-\mathrm{NMR}\right)$ spectra and the consecutive loss of $m / z 148\left(\mathrm{C}_{6} \mathrm{H}_{5} \mathrm{CH}=\mathrm{CHCOOH}\right), 122\left(\mathrm{C}_{6} \mathrm{H}_{5} \mathrm{COOH}\right)$ and 60 $\left(\mathrm{CH}_{3} \mathrm{COOH}\right)$ units in the mass spectrum (MS). The ${ }^{1} \mathrm{H}-\mathrm{NMR}$ spectrum of 1 showed three singlets at $\delta 1.63-1.80$, which were attributed to three quaternary methyl groups. The signals observed at $\delta_{\mathrm{H}} 5.22,5.46,5.57,5.66$, and 6.13 were assigned to the protons attached to the carbon atoms bearing the secondary ester groups. One $\mathrm{AB}$ quartet at $\delta_{\mathrm{H}} 4.75$ and 4.98 was assigned to the methylene-bearing primary ester group. The ${ }^{13} \mathrm{C}-\mathrm{NMR}$. spectrum of 1 showed the presence of three methyls, two methylenes, six methines, four quaternary carbons, and three acetate, one benzoate, and one cinnamate esters. These results were consistent with a 
TABLE I. Sesquiterpense from T. wilfordii Hook fil. var. regelii

\begin{tabular}{llllll}
\hline \hline Triptofordin & Mol. formula & $\mathrm{M}^{+}$ & $\mathrm{mp}\left({ }^{\circ} \mathrm{C}\right)$ & {$[\alpha]_{\mathrm{D}}$} & Esters \\
\hline F-1 (1) & $\mathrm{C}_{37} \mathrm{H}_{42} \mathrm{O}_{13}$ & 694 & $252-255$ & +27.5 & $\mathrm{Ac} \times 3, \mathrm{Bz}, \mathrm{Cin}$ \\
$\mathrm{F}-2(\mathbf{7})$ & $\mathrm{C}_{35} \mathrm{H}_{40} \mathrm{O}_{13}$ & 668 & $105-109$ & +37.3 & $\mathrm{Ac} \times 3, \mathrm{Bz} \times 2$ \\
$\mathrm{~F}-3(\mathbf{1 0})$ & $\mathrm{C}_{37} \mathrm{H}_{42} \mathrm{O}_{14}$ & 710 & $200-205$ & +20.1 & $\mathrm{Ac} \times 4, \mathrm{Bz} \times 2$ \\
F-4 (5) & $\mathrm{C}_{35} \mathrm{H}_{40} \mathrm{O}_{12}$ & 652 & $217-224$ & +18.8 & $\mathrm{Ac} \times 2, \mathrm{Bz}, \mathrm{Cin}$ \\
\hline
\end{tabular}

Ac, acetate; $\mathrm{Bz}$, benzoate; Cin, trans-cinnamate.

TABLE II. NOE in Triptofordin F-1 (1) $\left(\mathrm{CDCl}_{3}, 200 \mathrm{MHz}\right)$

\begin{tabular}{ccc}
\hline \hline Irradiate & Observe & Percentage enhancement \\
\hline H-9 & H-1 & 10 \\
H-12 & H-9 & 20 \\
H-13 & H-7 & 14 \\
H-14 & H-15 & 10 \\
H-14 & H-6 & 9 \\
\hline
\end{tabular}

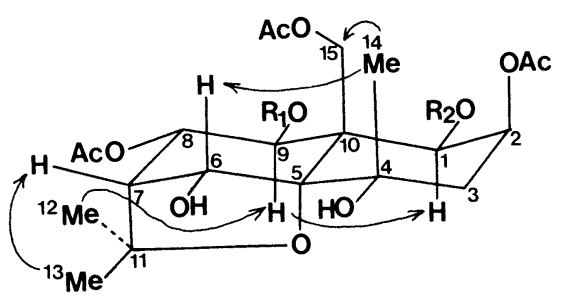

molecular formular for 1 of $\mathrm{C}_{37} \mathrm{H}_{42} \mathrm{O}_{13}$. It was concluded that $\mathbf{1}$ was a derivative of the dihydroagarofuran skeleton of the sesquiterpene polyol esters found in the Celastraceae. ${ }^{7)}$ The presence of the same skeleton in the compounds 7, 10, and 5 was also indicated from the analysis of spectral data. The physical and spectral properties of the isolated sesquiterpenes are summarized in Table I. From a comparison of the ${ }^{1} \mathrm{H}-\mathrm{NMR}$ data for 1 and known sesquiterpenes, ${ }^{8)}$ the signal at $\delta_{\mathrm{H}} 2.60$ (br d, $J=3.2 \mathrm{~Hz}$ ) was assigned to $\mathrm{H}-7$. The signals at $\delta_{\mathrm{H}} 5.66(\mathrm{dd}, J=10.0$ and $3.2 \mathrm{~Hz})$ and $6.13(\mathrm{~d}, J=10.0 \mathrm{~Hz})$ were assigned to $\mathrm{H}-8$ and $\mathrm{H}-9$, respectively, on the basis of spin decoupling experiments. The coupling constant $(J=10.0 \mathrm{~Hz})$ of $\mathrm{H}-8$ and $\mathrm{H}-9$ was indicative of a diaxial relationship. The signal at $\delta_{\mathrm{H}} 5.22$ (br d to br s with $\mathrm{D}_{2} \mathrm{O}$ change) was assigned to $\mathrm{H}-6$ from the small coupling with $\mathrm{H}-7$. The signal at $\delta_{\mathrm{H}} 5.46$ was assigned to $\mathrm{H}_{\mathrm{eq}}-2$ in the dihydroagarofuran skeleton from the coupling constants, and this proton was coupled with a signal at $\delta_{\mathrm{H}} 5.57$, assigned to $\mathrm{H}-1$ or $\mathrm{H}-3$. The assignment of $\mathrm{H}_{\mathrm{ax}}-1$ for this signal is more likely, because all the sesquiterpenes with a dihydroagarofuran skeleton isolated from Celastraceae have an equatorial ester on $\mathrm{C}-1{ }^{8)}$ The tertiary hydroxy group responsible for the signal at $\delta_{\mathrm{H}} 3.16$ (exchangeable with $\mathrm{D}_{2} \mathrm{O}$ ) is placed at $\mathrm{C}-4$, since compound 1 has three tertiary methyl groups.

The relative stereochemistry and the location of ester function on C-1 and C-15 were determined by nuclear Overhauser effect (NOE) experiments (Table II). Irradiation of $\mathrm{H}-14$ $\left(\mathrm{CH}_{3}\right)$ produced an enhancement in the intensity of the $\mathrm{H}-6$ and $\mathrm{H}-15\left(\mathrm{CH}_{2}\right)$ signals, indicating the stereochemistry at C-6 and the presence of one ester function on $\mathrm{C}-15$. When the $\mathrm{H}-12\left(\mathrm{CH}_{3}\right)$ signal was irradiated, an increase of the $\mathrm{H}-9$ signal occurred, while irradiation at the $\mathrm{H}-9$ signal produced an enhancement in the intensity of the $\mathrm{H}-1$, which indicated that $\mathrm{H}-1$ and $\mathrm{H}-9$ are axial, and one of the ester functions is present at $\mathrm{C}-1$.

Next, we confirmed the linking sites of the ester groupings. The presence of one hydroxy group on C-6 was elucidated in the following manner. The ${ }^{1} \mathrm{H}-\mathrm{NMR}$ signal assignable to $6-\mathrm{H}$ 
TABle III. ${ }^{1}$ H-NMR Data for Triptofordins F-1 (1), F-2 (7), F-3 (10), F-4 (5) and Compounds 9, 20

\begin{tabular}{|c|c|c|c|c|c|c|}
\hline & 1 & 7 & 10 & 5 & 9 & 20 \\
\hline $\mathrm{H}-1$ & $\begin{array}{l}5.57 \mathrm{~d} \\
(3.4)\end{array}$ & $\begin{array}{l}5.55 \mathrm{~d} \\
(3.4)\end{array}$ & $\begin{array}{l}5.75 \mathrm{~d} \\
(3.4)\end{array}$ & $\begin{array}{l}6.28 \mathrm{~d} \\
(3.7)\end{array}$ & $5.36 \mathrm{~m}$ & $\begin{array}{l}5.46 \mathrm{~d} \\
(3.4)\end{array}$ \\
\hline $\mathrm{H}-2$ & $\begin{array}{l}5.46 \text { ddd } \\
(3.4) \\
(3.4) \\
(3.4)\end{array}$ & $\begin{array}{l}5.39 \text { ddd } \\
(3.4) \\
(2.9) \\
(2.9)\end{array}$ & $\begin{array}{l}5.46 \text { ddd } \\
(3.4) \\
(3.4) \\
(3.0)\end{array}$ & $6.04 \mathrm{~m}$ & $5.36 \mathrm{~m}$ & $5.29 \mathrm{~m}$ \\
\hline $\mathrm{H}-3$ & - & $\begin{array}{l}2.02 \mathrm{dd} \\
(14.9) \\
(2.9)\end{array}$ & - & - & - & - \\
\hline $\mathrm{H}-6$ & $\begin{array}{l}5.22 \text { br d } \\
(5.1)\end{array}$ & $\begin{array}{l}5.25 \text { br d } \\
(5.1)\end{array}$ & $6.60 \mathrm{brs}$ & $5.70 \mathrm{~m}$ & $6.47 \mathrm{brs}$ & $\begin{array}{l}5.20 \text { br d } \\
(5.1)\end{array}$ \\
\hline $\mathrm{H}-7$ & $\begin{array}{l}2.60 \mathrm{br} \mathrm{d} \\
(3.2)\end{array}$ & $\begin{array}{l}2.79 \text { br d } \\
(3.3)\end{array}$ & $\begin{array}{l}2.50 \text { br d } \\
(3.3)\end{array}$ & $\begin{array}{l}2.99 \mathrm{br} \mathrm{d} \\
(3.3)\end{array}$ & $\begin{array}{l}2.43 \mathrm{brd} \\
(3.3)\end{array}$ & $\begin{array}{l}2.60 \mathrm{br} \mathrm{d} \\
(3.4)\end{array}$ \\
\hline $\mathrm{H}-8$ & $\begin{array}{l}5.66 \mathrm{dd} \\
(10.0) \\
(3.2)\end{array}$ & $\begin{array}{l}5.75 \mathrm{dd} \\
(9.8) \\
(3.3)\end{array}$ & $\begin{array}{l}5.74 \mathrm{dd} \\
(9.8) \\
(3.3)\end{array}$ & $\begin{array}{l}4.88 \mathrm{dd} \\
(9.3) \\
(3.3)\end{array}$ & $\begin{array}{l}5.49 \mathrm{dd} \\
(9.5) \\
(3.3)\end{array}$ & $4.28 \mathrm{~m}$ \\
\hline H-9 & $\begin{array}{l}6.13 \mathrm{~d} \\
(10.0)\end{array}$ & $\begin{array}{l}6.27 \mathrm{~d} \\
(9.8)\end{array}$ & $\begin{array}{l}6.12 \mathrm{~d} \\
(9.8)\end{array}$ & $\begin{array}{l}6.78 \mathrm{~d} \\
(9.3)\end{array}$ & $\begin{array}{l}5.65 \mathrm{~d} \\
(9.5)\end{array}$ & $\begin{array}{l}5.89 \mathrm{~d} \\
(9.5)\end{array}$ \\
\hline $\mathrm{H}-12$ & $1.74 \mathrm{~s}$ & $1.81 \mathrm{~s}$ & $1.52 \mathrm{~s}^{a)}$ & $1.82 \mathrm{~s}^{a)}$ & $1.47 \mathrm{~s}^{a)}$ & $1.63 \mathrm{~s}^{a)}$ \\
\hline $\mathrm{H}-13$ & $1.63 \mathrm{~s}$ & $1.61 \mathrm{~s}$ & $1.59 \mathrm{~s}^{a)}$ & $2.11 \mathrm{~s}^{a)}$ & $1.53 \mathrm{~s}^{a)}$ & $1.77 \mathrm{~s}^{a)}$ \\
\hline H-14 & $1.80 \mathrm{~s}$ & $1.81 \mathrm{~s}$ & $1.73 \mathrm{~s}^{a)}$ & $2.16 \mathrm{~s}^{a)}$ & $1.62 \mathrm{~s}^{a)}$ & $1.77 \mathrm{~s}^{a)}$ \\
\hline $\mathrm{H}-15$ & $\begin{array}{l}4.75 \\
4.98 \mathrm{ABq} \\
(13.2)\end{array}$ & $\begin{array}{l}4.77 \\
4.85 \mathrm{ABq} \\
(13.7)\end{array}$ & $\begin{array}{l}4.90 \\
5.04 \mathrm{ABq} \\
(13.2)\end{array}$ & $\begin{array}{l}5.36 \\
5.53 \mathrm{ABq} \\
(13.4)\end{array}$ & $\begin{array}{l}4.65 \\
4.74 \mathrm{ABq} \\
(13.0)\end{array}$ & $4.80 \mathrm{~s}$ \\
\hline $4-\mathrm{OH}$ & $3.16 \mathrm{~s}$ & $3.16 \mathrm{~s}$ & $2.81 \mathrm{~s}$ & - & $2.73 \mathrm{~s}$ & $3.14 \mathrm{~s}$ \\
\hline $\mathrm{Ac}$ & $\begin{array}{l}1.85,2.08, \\
2.36\end{array}$ & $\begin{array}{l}1.53,2.11, \\
2.36\end{array}$ & $\begin{array}{l}1.81,2.04 \\
2.16,2.43\end{array}$ & $2.07,2.13$ & $\begin{array}{l}1.89,1.97 \\
1.99,2.11 \\
2.12,2.29\end{array}$ & $\begin{array}{l}1.46,2.11 \\
2.24\end{array}$ \\
\hline
\end{tabular}

1: benzoate and cinnamate $[5.69$ and 7.39 (each $1 \mathrm{H}, \mathrm{ABq}, J=16.0), 6.96-7.74(10 \mathrm{H})] ;$ : benzoate $[7.31-7.91(10 \mathrm{H})]$; 10: benzoate [6.89-7.56 (10H)]; 5 : benzoate and cinnamate [6.12 and 7.68 (each $1 \mathrm{H}, \mathrm{ABq}, J=16.0), 6.93-8.12(10 \mathrm{H})$ ]; 20: benzoate $[7.43-7.97(5 \mathrm{H})]$. Figures in parentheses are coupling constants in $\mathrm{Hz}$, run at $200 \mathrm{MHz}$ in $\mathrm{CDCl}_{3}(\mathbf{1}, \mathbf{7}, \mathbf{1 0}, 9$ and 20$)$ and $\mathrm{C}_{5} \mathrm{D}_{5} \mathrm{~N}$ (5). a) Values in each column may be interchanged.

changed from a doublet to a broad singlet upon addition of $\mathrm{D}_{2} \mathrm{O}$. On acetylation, 1 gave a monoacetylated compound 2. In the ${ }^{1} \mathrm{H}-\mathrm{NMR}$ spectrum of 2 , the signal assignable to $\mathrm{H}-6$ showed a downfield shift to $\delta_{\mathrm{H}} 6.58$ (brs) as compared with 1 [ $\delta_{\mathrm{H}} 5.22$ (brd)]. On partial hydrolysis using $\mathrm{HCl}$-dioxane, 1 gave $5, \mathrm{C}_{35} \mathrm{H}_{40} \mathrm{O}_{12}, \mathrm{mp} 217-224{ }^{\circ} \mathrm{C}$, whose ${ }^{1} \mathrm{H}-\mathrm{NMR}$ spectrum showed one acetate missing compared with that of 1 (Chart 1 iii). The signal assignable to $\mathrm{H}-8$ of 5 showed an upfield shift to $\delta_{\mathrm{H}} 4.88(\mathrm{dd}, J=9.3$ and $3.3 \mathrm{~Hz}$ ), indicating the presence of one acetate ester of 1 at $\mathrm{C}-8$. The remaining locations of one benzoate, one cinnamate, and two acetate esters were determined by chemical correlation with the known compound 6. ${ }^{7}$ The $\mathrm{NaBH}_{4}$ reduction of 6 gave two products $3, \mathrm{C}_{37} \mathrm{H}_{42} \mathrm{O}_{13}$ and 5 (Chart $1 \mathrm{iv}$ ). Thus, the structure of triptofordin F-1 (1) was determined to be as shown in Chart 1.

Triptofordin F-2 (7) has two benzoate and three acetate ester groups (Table I). The ${ }^{13} \mathrm{C}$ NMR spectrum of 7 was very similar to that of 1 except for the ester groups; also the ${ }^{1} \mathrm{H}$ NMR spectra of both compounds showed very similar chemical shifts and coupling constants for the dihydroagarofuran skeleton, suggesting the same stereochemistry for both compounds. Compound 1 was hydrolyzed by using $\mathrm{NaOEt}-\mathrm{EtOH}$ to give a heptahydroxy derivative 4 (Chart 1 ii), which was acetylated to give a hexaacetyl derivative $9\left[\mathrm{C}_{27} \mathrm{H}_{38} \mathrm{O}_{14}\right.$, $\delta_{\mathrm{H}} 1.89,1.97,1.99,2.11,2.12$, and $2.29\left(\right.$ each $\left.\left.3 \mathrm{H}, \mathrm{s}, \mathrm{COCH}_{3}\right)\right](\mathrm{Chart} 1 \mathrm{i})$. The same reaction of 7 gave 9. 
TABLE IV. ${ }^{13} \mathrm{C}-\mathrm{NMR}$ Data for the Skeletal Carbons of Triptofordins F-1 (1), F-2 (7), F-3 (10), F-4 (5) and Compound 4

\begin{tabular}{cccccc}
\hline \hline & $\mathbf{1}$ & $\mathbf{7}$ & $\mathbf{1 0}$ & $\mathbf{5}$ & $\mathbf{4}$ \\
\hline $\mathrm{C}-1$ & $75.5(\mathrm{~d})^{a)}$ & $75.0(\mathrm{~d})^{a)}$ & $75.4(\mathrm{~d})$ & $76.9(\mathrm{~d})$ & $77.7(\mathrm{~d})$ \\
C-2 & $67.8(\mathrm{~d})$ & $67.5(\mathrm{~d})$ & $68.1(\mathrm{~d})$ & $68.8(\mathrm{~d})$ & $70.4(\mathrm{~d})$ \\
C-3 & $41.1(\mathrm{t})$ & $41.3(\mathrm{t})$ & $42.0(\mathrm{t})$ & $40.4(\mathrm{t})$ & $44.3(\mathrm{t})$ \\
C-4 & $72.2(\mathrm{~s})$ & $72.2(\mathrm{~s})$ & $69.6(\mathrm{~s})$ & $72.2(\mathrm{~s})$ & $73.1(\mathrm{~s})$ \\
C-5 & $91.5(\mathrm{~s})$ & $91.6(\mathrm{~s})$ & $92.3(\mathrm{~s})$ & $92.3(\mathrm{~s})$ & $92.8(\mathrm{~s})$ \\
C-6 & $76.9(\mathrm{~d})$ & $76.9(\mathrm{~d})$ & $75.4(\mathrm{~d})$ & $79.9(\mathrm{~d})$ & $82.1(\mathrm{~d})$ \\
C-7 & $53.7(\mathrm{~d})$ & $53.6(\mathrm{~d})$ & $52.4(\mathrm{~d})$ & $57.6(\mathrm{~d})$ & $57.3(\mathrm{~d})$ \\
C-8 & $73.8(\mathrm{~d})$ & $75.3(\mathrm{~d})^{a)}$ & $73.8(\mathrm{~d})$ & $73.8(\mathrm{~d})$ & $75.5(\mathrm{~d})$ \\
C-9 & $75.1(\mathrm{~d})^{a)}$ & $\left.75.1(\mathrm{~d})^{a}\right)$ & $75.4(\mathrm{~d})$ & $76.9(\mathrm{~d})$ & $78.5(\mathrm{~d})$ \\
C-10 & $51.2(\mathrm{~s})$ & $50.9(\mathrm{~s})$ & $52.0(\mathrm{~s})$ & $51.8(\mathrm{~s})$ & $52.4(\mathrm{~s})$ \\
C-11 & $84.6(\mathrm{~s})$ & $84.6(\mathrm{~s})$ & $84.4(\mathrm{~s})$ & $84.6(\mathrm{~s})$ & $83.5(\mathrm{~s})$ \\
C-12 & $26.2(\mathrm{q})$ & $26.4(\mathrm{q})$ & $25.7(\mathrm{q})$ & $27.1(\mathrm{q})$ & $27.7(\mathrm{q})$ \\
C-13 & $30.1(\mathrm{q})$ & $30.1(\mathrm{q})$ & $29.7(\mathrm{q})$ & $30.7(\mathrm{q})$ & $30.8(\mathrm{q})$ \\
C-14 & $24.4(\mathrm{q})$ & $24.4(\mathrm{q})$ & $24.8(\mathrm{q})$ & $27.1(\mathrm{q})$ & $27.2(\mathrm{q})$ \\
C-15 & $61.4(\mathrm{t})$ & $61.6(\mathrm{t})$ & $61.5(\mathrm{t})$ & $62.5(\mathrm{t})$ & $61.4(\mathrm{t})$ \\
\hline
\end{tabular}

a) Values in each column may be interchanged. Run at $50.1 \mathrm{MHz}$ in $\mathrm{CDCl}_{3}(\mathbf{1}, 7, \mathbf{1 0}$, and $\mathbf{5})$ and $\mathrm{C}_{5} \mathrm{D}_{5} \mathrm{~N}(\mathbf{4})$.

The locations of ester groups of triptofordin F-2 (7) were determined as follows. The chemical shift of $\mathrm{H}-6$ of 7 was almost the same as that of 1 . On acetylation, compound 7 gave a monoacetylated product $8, \mathrm{C}_{37} \mathrm{H}_{42} \mathrm{O}_{14}$ in which the signal assignable to $\mathrm{H}-6\left(\delta_{\mathrm{H}} 6.68\right.$, br s) was shifted downfield from that of $7\left(\delta_{\mathrm{H}} 5.25\right.$, brd), indicating the presence of one hydroxy group of compound 7 at $\mathrm{C}-6$. The partial hydrolysis of 7 by using $0.2 \mathrm{M} \mathrm{K}_{2} \mathrm{CO}_{3}-\mathrm{MeOH}$ gave a monobenzoate derivative 12 (Chart 2 iii). In the ${ }^{1} \mathrm{H}-\mathrm{NMR}$ spectrum of 12 , the signal at $\delta_{\mathrm{H}}$ $4.28(\mathrm{~m})$ was assigned to $\mathrm{H}-8$ on a carbon bearing a hydroxy group, indicating the presence of one benzoate ester at C-8 in the parent compound 7. Also, the site of the second benzoyl ester of 7 at C-9 could be deduced from the ${ }^{1} \mathrm{H}-\mathrm{NMR}$ spectrum. Previous workers have drawn attention to the unusual diamagnetic shift of the acetate methyl signal $\left(\delta_{\mathrm{H}} 1.5-1.7\right)$ which arises when an equatorial acetate on $\mathrm{C}-1$ is shielded by an aromatic ester on C-9. ${ }^{9)}$ One of the acetate methyl signals of 7 appeared in an unusual region $\left(\delta_{\mathrm{H}} 1.53\right)$. Thus, the ${ }^{1} \mathrm{H}-\mathrm{NMR}$ data indicated the ester residues on $\mathrm{C}-1$ and $\mathrm{C}-9$ to be acetate and benzoate. Furthermore, the presence of one benzoyl ester on C-9 was determined by chemical correlation with a known compound. ${ }^{6}$ Sodium borohydride reduction of the known compound 11 gave two compounds, $12\left(\mathrm{C}_{28} \mathrm{H}_{36} \mathrm{O}_{12}\right)$ and $13\left(\mathrm{C}_{30} \mathrm{H}_{38} \mathrm{O}_{13}\right)$, indicating the presence of one benzoyl ester on $\mathrm{C}-9$, and the presence of acetate esters on $\mathrm{C}-1, \mathrm{C}-2$, and $\mathrm{C}-15$. From these results the structure of triptofordin F-2 was formulated as 7, as shown in Chart 1.

Triptofordin F-3 (10) has two benzoate and four acetate esters in the molecule. The ${ }^{1} \mathrm{H}-$ and ${ }^{13} \mathrm{C}$-NMR spectra of $\mathbf{1 0}$ were also very similar to those of compounds $\mathbf{1}$ and $\mathbf{7}$ except for the ester signals, suggesting that these compounds have the same stereochemistry in the dihydroagarofuran skeleton. The ester groups of compound $\mathbf{1 0}$ were similar to those of the known compound 14 except for one acetate. On $\mathrm{NaBH}_{4}$ reduction, 14 gave compounds 15 and 16. Compound 16 was acetylated to give 10. This result indicated the presence of benzoyl esters at C-1 and C-9 of $\mathbf{1 0}$ and the presence of acetyl esters at C-2, C-6, C-8, and C-15, as shown in Chart 1.

Triptofordin F-4 (5) has one benzoyl ester, one cinnamoyl ester, two acetyl esters and three hydroxy groups in the molecule. From the ${ }^{1} \mathrm{H}-\mathrm{NMR}$ spectrum, $\mathbf{5}$ was postulated to be the 8-deacetyl derivative of 1 . Actually, 5 was derived from 1 and 6 . The ${ }^{1} \mathrm{H}$ - and ${ }^{13} \mathrm{C}-\mathrm{NMR}$ 

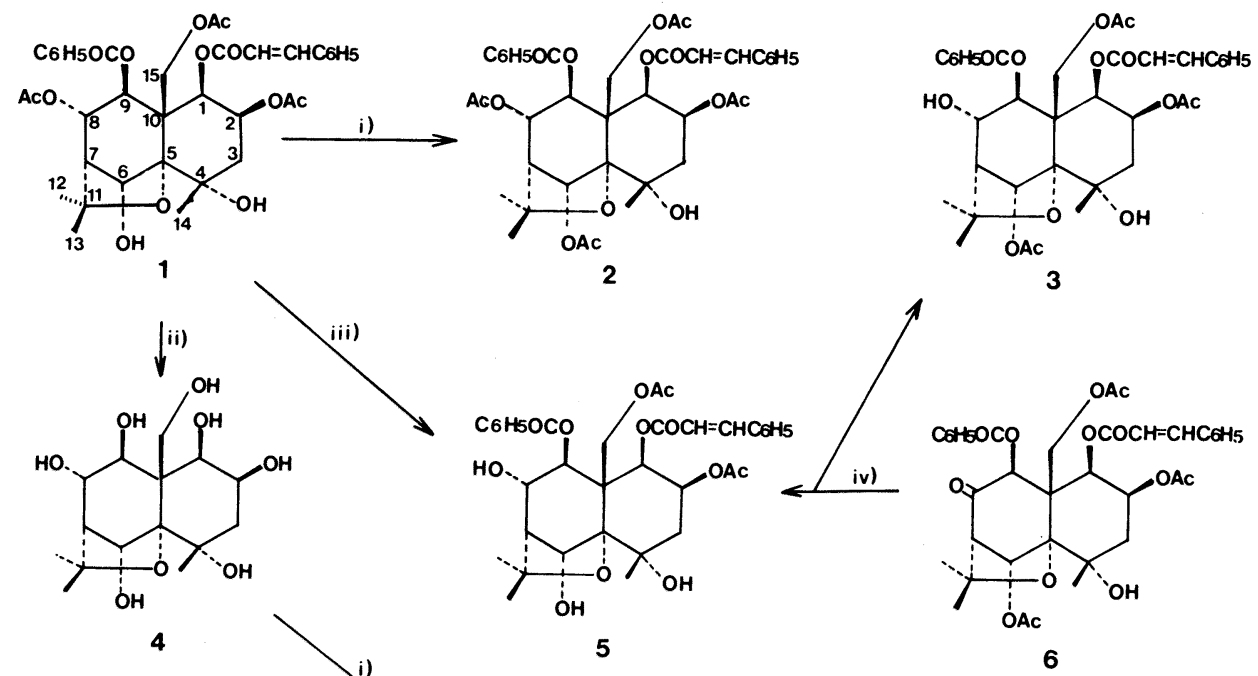

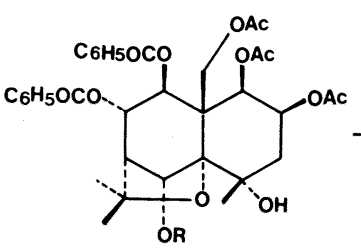

$7: R=H$
$8: R=A C$ ii),
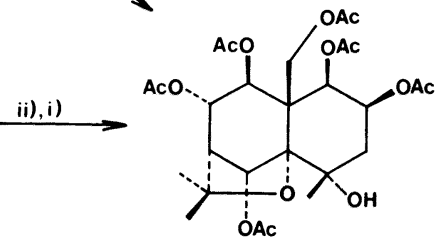

9

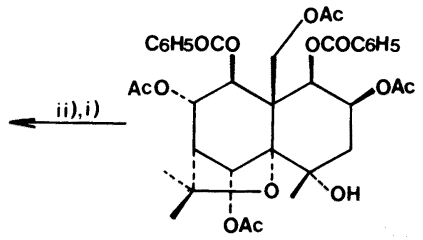

10

i) Ac2O-pyridine; ii) $\mathrm{NaOEt}-\mathrm{EtOH}$; iii) $\mathrm{HCl}$-dioxane; iv) $\mathrm{NaBH} 4-\mathrm{MeOH}$

Chart 1

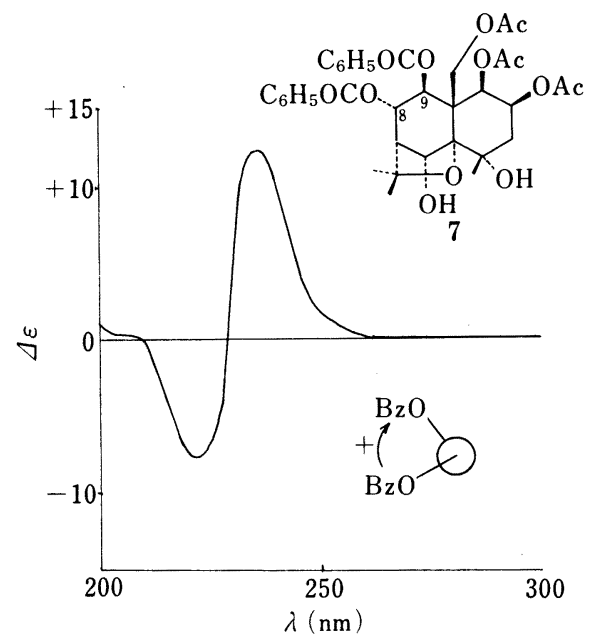

Fig. 1. CD Spectrum of Triptofordin F-2 (2)

assignments of the isolated compounds and derivatives are summarized in Tables II and III.

The absolute configurations of these compounds were determined as follows. The circular dichroism (CD) spectrum (Fig. 1) of triptofordin F-2 (7) showed a split Cotton curve 


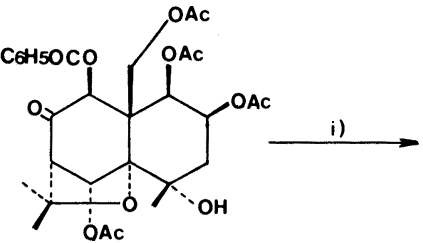

11

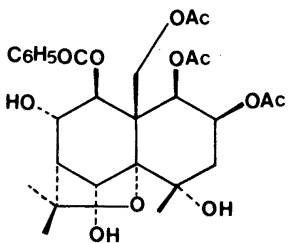

12

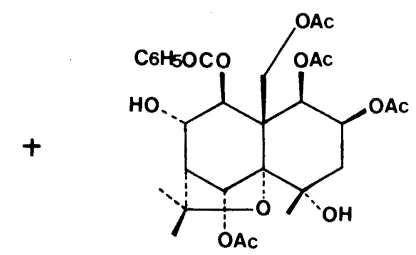

9

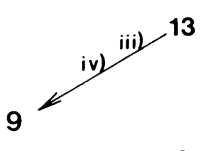

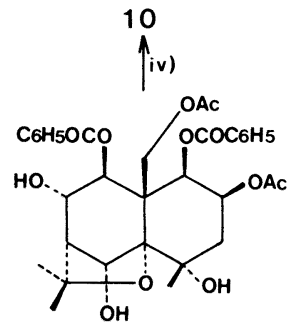

16

Chart 2

due to dibenzoate chirality, ${ }^{10)}$ with $[\theta]_{237}+44700,[\theta]_{224}-30200$. This indicated that the absolute configuration of 7 was $8 \mathrm{~S}$ and $9 \mathrm{~S}$. The absolute configurations of $\mathbf{1}$ and $\mathbf{1 0}$ were considered to be the same as that of $\mathbf{9}$. The absolute configuration of 5 was also confirmed by correlation with 1 . The absolute configurations of $\mathbf{6}, \mathbf{1 1}$, and $\mathbf{1 4}$, for which only relative configurations $^{6.7)}$ were reported, were determined to be the same as above from the correlations with $\mathbf{5 , 7}$, and $\mathbf{1 0}$, respectively.

\section{Experimental}

Melting points were taken on a Yanagimoto melting point apparatus and are uncorrected. IR spectra were recorded on a Hitachi type 215 spectrometer for $\mathrm{KBr}$ disks. ${ }^{1} \mathrm{H}$ - and ${ }^{13} \mathrm{C}$-NMR spectra were taken with a JEOL JNM FX 200 spectrometer for solutions in deuteriochloroform or $d_{5}$-pyridine. Tetramethylsilane was used as an internal standard and chemical shifts are given in $\delta(\mathrm{ppm})$ values. MS were determined with a JEOL JMS D-300 spectrometer. UV spectra were recorded with a Hitachi type 330 spectrometer for solutions in methanol. Optical rotations were measured with a Union Giken PM-201 polarimeter. CD were taken with a JASCO J-500C spectropolarimeter. Kiesel gel 60 (70-230 mesh or $230-400$ mesh, Merck) and Sephadex LH-20 (Pharmacia) were used for column chromatography, and precoated silica gel plates $F_{254}(0.25$ and $0.5 \mathrm{~mm}$ in tickness $)$ were used for thin leyer chromatography (TLC).

Isolation of Triptofordins F-1 (1), F-2 (7), F-3 (10), and F-4 (5) Extraction and fractionation by using silica gel column chromatography were described in a previous paper. $\left.{ }^{6}\right)$ Fraction $8(2.52 \mathrm{~g})$, containing 7 and 10, was chromatographed on a silica gel column $\left(\mathrm{CHCl}_{3}:\right.$ acetone $\left.=19: 1\right)$ to give fr. $8-1(1.50 \mathrm{~g})$ and fr. $8-2(0.79 \mathrm{~g})$. Fraction 8-1 was further chromatographed on a silica gel column $\left(\mathrm{CHCl}_{3}:\right.$ acetone $\left.=9: 1\right)$ to give fr. $8-1-1(0.36 \mathrm{~g})$ and fr. 8-1-2 $(1.10 \mathrm{~g})$. Fraction 8-1-2 was chromatographed on a silica gel column (hexane $: \mathrm{EtOAc}=2: 3$ ) and crystallized from $\mathrm{MeOH}$ to give $10(14 \mathrm{mg})$. Fraction 8-2 was chromatographed on a silica gel column $\left(\mathrm{CHCl}_{3}:\right.$ acetone $\left.=19: 1\right)$ to give $7(59 \mathrm{mg})$. Fraction $10(1.86 \mathrm{~g})$ containing 1 was chromatographed successively on a Sephadex LH-20 column $\left(\mathrm{CHCl}_{3}: \mathrm{MeOH}=3: 2\right)$ and a silica gel column $\left(\mathrm{CH}_{2} \mathrm{Cl}_{2}: \mathrm{MeOH}=39: 1\right.$ and then $\mathrm{CHCl}_{3}:$ acetone $\left.=19: 1\right)$, and crystallized from $\mathrm{MeOH}$ to give $1(64 \mathrm{mg})$. Fraction $12(0.98 \mathrm{~g})$ was chromatographed on a silica gel column $\left(\mathrm{CH}_{2} \mathrm{Cl}_{2}: \mathrm{MeOH}=39: 1\right.$ and then hexane $\left.: \mathrm{EtOAc}=2: 3\right)$ to give fr. $12-2(97 \mathrm{mg})$, which was crystallized from $\mathrm{MeOH}$ to give $5(16 \mathrm{mg})$.

Triptofordin F-1 (1), colorless needles, mp $252-255^{\circ} \mathrm{C},[\alpha]_{\mathrm{D}}^{27}+27.5^{\circ}(c=0.3, \mathrm{MeOH})$. IR $v_{\max } \mathrm{cm}^{-1}: 3450$ 
$(\mathrm{OH}), 1740$ and 1712 (COO), 1630, 1280, 1030, 710. UV $\lambda_{\max }^{\mathrm{MeOH}} \mathrm{nm}(\varepsilon): 222$ (18800), 226 (19800), 233 (15600), 284 (17800). EI-MS $m / z$ (rel. int): $694[\mathrm{M}]^{+}(0.2), 679\left[\mathrm{M}-\mathrm{CH}_{3}\right]^{+}(1.5), 634\left[\mathrm{M}-\mathrm{CH}_{3} \mathrm{COOH}\right]^{+}(3.2), 546[\mathrm{M}-$ $\left.\mathrm{C}_{6} \mathrm{H}_{5} \mathrm{CH}=\mathrm{CHCOOH}\right]^{+}(1.59), 512\left[\mathrm{M}-\mathrm{C}_{6} \mathrm{H}_{5} \mathrm{COOH}-\mathrm{CH}_{3} \mathrm{COOH}\right]^{+}(80.7), 486\left[\mathrm{M}-\mathrm{C}_{6} \mathrm{H}_{5} \mathrm{CH}=\mathrm{CHCOOH}-\right.$ $\left.\mathrm{CH}_{3} \mathrm{COOH}\right]^{+}$(1.5), 471 (1.3), $426\left[\mathrm{M}-\mathrm{C}_{6} \mathrm{H}_{5} \mathrm{CH}=\mathrm{CHCOOH}-2 \times \mathrm{CH}_{3} \mathrm{COOH}\right]^{+}$(4.7), 320 (6.6), $131\left[\mathrm{C}_{6} \mathrm{H}_{5} \mathrm{CH}=\right.$ $\mathrm{CHCO}^{+}(100), 105\left[\mathrm{C}_{6} \mathrm{H}_{5} \mathrm{CO}\right]^{+}$(94). FAB-MS $m / z: 717[\mathrm{M}+\mathrm{Na}]^{+}$, HR-MS m/z: Calcd for $\mathrm{C}_{37} \mathrm{H}_{42} \mathrm{O}_{13}: 694.2625$. Found: 694.2660. ${ }^{1} \mathrm{H}-\mathrm{NMR}\left(\mathrm{C}_{5} \mathrm{D}_{5} \mathrm{~N}\right) \delta: 1.78,1.90,2.15\left(\right.$ each $\left.3 \mathrm{H}, \mathrm{s}, \mathrm{CH}_{3}\right), 1.85,2.08,2.33\left(\right.$ each $\left.3 \mathrm{H}, \mathrm{s}, \mathrm{COCH}_{3}\right)$, $2.90(1 \mathrm{H}, \mathrm{d}, J=3.1 \mathrm{~Hz}, \mathrm{H}-7), 5.29,5.56($ each $1 \mathrm{H}, \mathrm{ABq}, J=13.3 \mathrm{~Hz}, \mathrm{H}-15), 5.79(1 \mathrm{H}, \mathrm{d}, J=5.4 \mathrm{~Hz}, \mathrm{H}-6), 6.02$ $(1 \mathrm{H}, \mathrm{m}, \mathrm{H}-2), 6.24(1 \mathrm{H}, \mathrm{d}, J=3.7 \mathrm{~Hz}, \mathrm{H}-1), 6.10(1 \mathrm{H}, \mathrm{dd}, J=10.1,3.1 \mathrm{~Hz}, \mathrm{H}-8), 6.15,7.70(\mathrm{each} 1 \mathrm{H}, \mathrm{ABq}$, $\left.J=15.9 \mathrm{~Hz}, \mathrm{C}_{6} \mathrm{H}_{5} \mathrm{CH}=\mathrm{CHCO}\right), 6.72(1 \mathrm{H}, \mathrm{d}, J=10.1, \mathrm{H}-9), 6.98-8.17(10 \mathrm{H}$, aromatic H). Anal. Calcd for $\mathrm{C}_{37} \mathrm{H}_{42} \mathrm{O}_{13} \cdot \mathrm{H}_{2} \mathrm{O}: \mathrm{C}, 62.35 ; \mathrm{H}, 6.22$. Found: $\mathrm{C}, 62.70 ; \mathrm{H}, 6.31$.

Triptofordin F-2 (7), colorless needles, mp 105-109 ${ }^{\circ} \mathrm{C},[\alpha]_{\mathrm{D}}^{27}+37.3^{\circ}(c=0.2, \mathrm{MeOH})$. IR $v_{\max } \mathrm{cm}^{-1}: 3430$ $(\mathrm{OH}), 1750$ and 1730 (COO), 1280, 1230, 1110, 1030, 710. UV $\lambda_{\max }^{\mathrm{MeOH}} \mathrm{nm}(\varepsilon): 231$ (22800), $274(2600), 281(2300)$. EİMS $m / z$ (rel. int): $668[\mathrm{M}]^{+}(0.1), 653\left[\mathrm{M}-\mathrm{CH}_{3}\right]^{+}(2.5), 608\left[\mathrm{M}-\mathrm{CH}_{3} \mathrm{COOH}\right]^{+}(1), 590(2), 546\left[\mathrm{M}-\mathrm{C}_{6} \mathrm{H}_{5} \mathrm{COOH}\right]^{+}$ (4), $488(2), 486\left[\mathrm{M}-\mathrm{C}_{6} \mathrm{H}_{5} \mathrm{COOH}-\mathrm{CH}_{3} \mathrm{COOH}\right]^{+}$(2.5), $453(2.5), 424\left[\mathrm{M}-2 \times \mathrm{C}_{6} \mathrm{H}_{5} \mathrm{COOH}\right]^{+}$(1), 202 (22), 164 (20), $105\left[\mathrm{C}_{6} \mathrm{H}_{5} \mathrm{CO}\right]^{+}(100)$; FAB-MS m/z: $691[\mathrm{M}+\mathrm{Na}]^{+}$; HR-MS: Calcd for $\mathrm{C}_{35} \mathrm{H}_{40} \mathrm{O}_{13}$ : 668.2469. Found: 668.2432 . Anal. Calcd for $\mathrm{C}_{35} \mathrm{H}_{40} \mathrm{O}_{13}$ : C, 62.86; H, 6.03. Found: C, 62.93; H, 6.22 ${ }^{1} \mathrm{H}-\mathrm{NMR}$ : see Table II; ${ }^{13} \mathrm{C}-\mathrm{NMR}$ : see Table III.

Triptofordin F-3 (10), colorless granules, mp $200-205^{\circ} \mathrm{C},[\alpha]_{\mathrm{D}}^{22}+20.1^{\circ}(c=0.2, \mathrm{MeOH})$. IR $v_{\max } \mathrm{cm}^{-1}: 3500$ $(\mathrm{OH}), 1750$ and 1730 (COO), 1280, 1240, 1100, 1020, 710. UV $\lambda_{\max }^{\mathrm{MeOH}} \mathrm{nm}(\varepsilon): 232$ (21400), $278(4100), 284(4000)$. EIMS $m / z$ (rel. int.): $710[\mathrm{M}]^{+}(0.1), 695\left[\mathrm{M}-\mathrm{CH}_{3}\right]^{+}(0.4), 692\left[\mathrm{M}-\mathrm{H}_{2} \mathrm{O}\right]^{+}(0.5), 650\left[\mathrm{M}-\mathrm{CH}_{3} \mathrm{COOH}\right]^{+}(1.8), 590$ $\left[\mathrm{M}-2 \times \mathrm{CH}_{3} \mathrm{COOH}\right]^{+}(2.4), 528\left[\mathrm{M}-\mathrm{C}_{6} \mathrm{H}_{5} \mathrm{COOH}-\mathrm{CH}_{3} \mathrm{COOH}\right]^{+}(0.7), 468\left[\mathrm{M}-\mathrm{C}_{6} \mathrm{H}_{5} \mathrm{COOH}-2 \times \mathrm{CH}_{3} \mathrm{COOH}\right]^{+}$

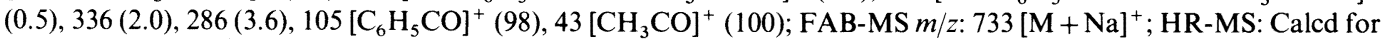
$\mathrm{C}_{37} \mathrm{H}_{42} \mathrm{O}_{14}$ : 710.2575. Found: 710.2545. Anal. Calcd for $\mathrm{C}_{37} \mathrm{H}_{42} \mathrm{O}_{14}$ : C, 62.53; H, 5.96. Found: C, 62.72; $\mathrm{H}, 6.14$.

Triptofordin F-4 (5), colorless needles, mp $217-224^{\circ} \mathrm{C},[\alpha]_{\mathrm{D}}^{27}+18.8^{\circ}(c=0.2, \mathrm{MeOH})$. IR $v_{\max } \mathrm{cm}^{-1}: 3450$ (OH), 1740 (COO), 1640, 1280, 1140, 1050, 710. UV $\lambda_{\max }^{\mathrm{MeOH}} \mathrm{nm}(\varepsilon): 223$ (17000), 226 (18000), 232 (15300), $284(14700)$. EI-MS $m / z$ (rel. int.): $652[\mathrm{M}]^{+}(0.1), 637\left[\mathrm{M}-\mathrm{CH}_{3}\right]^{+}(1.59), 634\left[\mathrm{M}-\mathrm{H}_{2} \mathrm{O}\right]^{+}(0.2), 616\left[\mathrm{M}-2 \times \mathrm{H}_{2} \mathrm{O}\right]^{+}(0.5), 426(1)$, $410(0.8), 131\left[\mathrm{C}_{6} \mathrm{H}_{5} \mathrm{CH}=\mathrm{CHCO}\right]^{+}(100), 105\left[\mathrm{C}_{6} \mathrm{H}_{5} \mathrm{CO}\right]^{+}(91), 43\left[\mathrm{CH}_{3} \mathrm{CO}\right]^{+}(40)$. FAB-MS $m / z: 675[\mathrm{M}+\mathrm{Na}]^{+}$. HR-MS: Calcd for $\mathrm{C}_{35} \mathrm{H}_{40} \mathrm{O}_{12}:$ 652.2520. Found: 652.2530. Anal. Calcd for $\mathrm{C}_{35} \mathrm{H}_{40} \mathrm{O}_{12} \cdot \mathrm{H}_{2} \mathrm{O}: \mathrm{C}, 62.67 ; \mathrm{H}, 6.25$. Found: C, 62.91; H, 6.23.

Acetylation of 1 - A solution of $1(5 \mathrm{mg})$ in $\mathrm{Ac}_{2} \mathrm{O}(0.5 \mathrm{ml})$ and pyridine $(0.5 \mathrm{ml})$ was stirred at $70^{\circ} \mathrm{C}$ for $17 \mathrm{~h}$, and the reaction mixture was worked up in the usual way to give 2 as an amorphous powder $(5 \mathrm{mg}) .{ }^{1} \mathrm{H}-\mathrm{NMR}$ $\left(\mathrm{CDCl}_{3}\right) \delta: 1.50,1.58,1.73\left(\right.$ each $\left.3 \mathrm{H}, \mathrm{s}, \mathrm{CH}_{3}\right), 1.86,2.06,2.15,2.42\left(\right.$ each $\left.3 \mathrm{H}, \mathrm{s}, \mathrm{COCH}_{3}\right), 2.50(1 \mathrm{H}, \mathrm{d}, J=3.2 \mathrm{~Hz}, \mathrm{H}-7)$, $3.66(1 \mathrm{H}, \mathrm{s}, 4-\mathrm{OH}), 4.85,4.94$ (each $1 \mathrm{H}, \mathrm{ABq}, J=15.9 \mathrm{~Hz}, \mathrm{H}-15), 5.45(1 \mathrm{H}, \mathrm{m}, \mathrm{H}-2), 5.57(1 \mathrm{H}, \mathrm{d}, J=3.4 \mathrm{~Hz}, \mathrm{H}-1)$, $5.68,7.39$ (each $\left.1 \mathrm{H}, \mathrm{d}, J=16.1 \mathrm{~Hz}, \mathrm{C}_{6} \mathrm{H}_{5} \mathrm{CH}=\mathrm{CHCO}\right), 5.76(1 \mathrm{H}, \mathrm{dd}, J=9.8,3.2 \mathrm{~Hz}, \mathrm{H}-8), 6.10(1 \mathrm{H}, \mathrm{d}, J=9.8 \mathrm{~Hz}, \mathrm{H}-$ 9), $6.58(1 \mathrm{H}, \mathrm{s}, \mathrm{H}-6), 6.96-7.77(10 \mathrm{H}$, aromatic $\mathrm{H})$.

Partial Hydrolysis of 1 - A solution of $1(39 \mathrm{mg})$ in $\mathrm{MeOH}(2 \mathrm{ml})$, dioxane $(3.5 \mathrm{ml})$ and $18 \% \mathrm{HCl}(1.5 \mathrm{ml})$ was stirred at $70^{\circ} \mathrm{C}$ for $89 \mathrm{~h}$, then the reaction mixture was evaporated in vacuo to give a residue. The residue was purified by silica gel column chromatography with hexane: EtOAc $=3: 2$ to give 5 as an amorphous powder $(9 \mathrm{mg}),[\alpha]_{\mathrm{D}}^{22}$ $+17^{\circ}(c=0.2, \mathrm{MeOH})$.

$\mathrm{NaBH}_{4}$ Reduction of 6 - A solution of $6(35 \mathrm{mg})$ and $\mathrm{NaBH}_{4}(5 \mathrm{mg})$ in $\mathrm{MeOH}(5 \mathrm{ml})$ was stirred at room temperature for $5 \mathrm{~min}$, then the reaction mixture was neutralized with diluted $\mathrm{HCl}$ and evaporated in vacuo to give a residue, which was purified by using preparative TLC $\left(\mathrm{CHCl}_{3}: \mathrm{MeOH}=97: 3\right)$ to give 3 as an amorphous powder $(8.6 \mathrm{mg})$ and $5(6.2 \mathrm{mg}) .3,{ }^{1} \mathrm{H}-\mathrm{NMR}\left(\mathrm{CDCl}_{3}\right) \delta: 1.26,1.49,1.78\left(\right.$ each $\left.3 \mathrm{H}, \mathrm{s},-\mathrm{CH}_{3}\right), 2.09,2.15,2.32($ each $3 \mathrm{H}, \mathrm{s}$, $\left.\mathrm{COCH}_{3}\right), 2.48(1 \mathrm{H}, \mathrm{d}, J=3.4 \mathrm{~Hz}, \mathrm{H}-7), 2.84(1 \mathrm{H}, \mathrm{br} \mathrm{s}, 4-\mathrm{OH}), 4.48(1 \mathrm{H}, \mathrm{dd}, J=10.0,3.4 \mathrm{~Hz}, \mathrm{H}-8), 4.86,5.03(\mathrm{each} 1 \mathrm{H}$, ABq, $J=13.4 \mathrm{~Hz}, \mathrm{H}-15), 5.42(1 \mathrm{H}, \mathrm{m}, \mathrm{H}-2), 5.60,7.35$ (each $\left.1 \mathrm{H}, \mathrm{d}, J=16.1 \mathrm{~Hz}, \mathrm{C}_{6} \mathrm{H}_{5} \mathrm{CH}=\mathrm{CHCO}\right), 5.60(1 \mathrm{H}, \mathrm{d}, J=$ $3.7 \mathrm{~Hz}, \mathrm{H}-1), 5.93(1 \mathrm{H}, \mathrm{d}, J=10.0 \mathrm{~Hz}, \mathrm{H}-9), 6.40(1 \mathrm{H}, \mathrm{s}, \mathrm{H}-6), 6.8-7.9(10 \mathrm{H}$, aromatic $\mathrm{H}) .5,[\alpha]_{\mathrm{D}}^{22}+19.6^{\circ}(c=0.2$, $\mathrm{MeOH}$ ), EI-MS $m / z$ (rel. int.): $694[\mathrm{M}]^{+}(0.1), 679\left[\mathrm{M}-\mathrm{CH}_{3}\right]^{+}(2), 661\left[\mathrm{M}-\mathrm{CH}_{3}-\mathrm{H}_{2} \mathrm{O}\right]^{+}(1), 634$ $\left[\mathrm{M}-\mathrm{CH}_{3} \mathrm{COOH}\right]^{+}(1), 574\left[\mathrm{M}-2 \times \mathrm{CH}_{3} \mathrm{COOH}\right]^{+}$(4), $131\left[\mathrm{C}_{6} \mathrm{H}_{5} \mathrm{CH}=\mathrm{CHCO}\right]^{+}(66), 105\left[\mathrm{C}_{6} \mathrm{H}_{5} \mathrm{CO}\right]^{+}(100), 43$ $\left[\mathrm{CH}_{3} \mathrm{CO}\right]^{+}$(30). HR-MS: Calcd for $\mathrm{C}_{37} \mathrm{H}_{42} \mathrm{O}_{13}$ : 694.2625. Found: 694.2624.

Hydrolysis of $1-$ A solution of $1(20 \mathrm{mg})$ in $0.1 \mathrm{M} \mathrm{NaOEt}-\mathrm{EtOH}(1 \mathrm{ml})$ was stirred at room temperature for $12 \mathrm{~h}$, then the reaction mixture was evaporated in vacuo to give a residue, which was chromatographed on a silica gel column (EtOAc: $\mathrm{MeOH}=5: 1)$ to give $4(9.6 \mathrm{mg}) .4{ }^{1} \mathrm{H}-\mathrm{NMR}\left(\mathrm{C}_{5} \mathrm{D}_{5} \mathrm{~N}\right) \delta: 1.77,1.94,2.36\left(\right.$ each $\left.3 \mathrm{H}, \mathrm{s},-\mathrm{CH}_{3}\right), 2.33$ $(1 \mathrm{H}, \mathrm{brd}, J=14 \mathrm{~Hz}, \mathrm{H}-3), 2.51(1 \mathrm{H}, \mathrm{dd}, J=14,3 \mathrm{~Hz}, \mathrm{H}-3), 2.84(1 \mathrm{H}, \mathrm{d}, J=2.7 \mathrm{~Hz}, \mathrm{H}-7), 3.61(1 \mathrm{H}, \mathrm{s}, \mathrm{OH}), 4.52(1 \mathrm{H}$, $\mathrm{m}, \mathrm{H}-2), 4.78\left(2 \mathrm{H}\right.$, br s, $\left.\mathrm{H}_{2}-15\right), 4.79(1 \mathrm{H}, \mathrm{m}, \mathrm{H}-8), 4.90(1 \mathrm{H}, \mathrm{m}, \mathrm{H}-1), 5.03(1 \mathrm{H}, \mathrm{d}, J=6.1 \mathrm{~Hz}, \mathrm{H}-6), 5.06(1 \mathrm{H}, \mathrm{brd}, J=$ $10 \mathrm{~Hz}, \mathrm{H}-9), 6.55(1 \mathrm{H}, \mathrm{d}, J=6.1 \mathrm{~Hz}, 6-\mathrm{OH}) .{ }^{13} \mathrm{C}-\mathrm{NMR}$ : see Table III.

Acetylation of 4 A solution of $4(8 \mathrm{mg})$ in $\mathrm{Ac}_{2} \mathrm{O}(0.5 \mathrm{ml})$ and pyridine $(0.5 \mathrm{ml})$ was stirred at $70^{\circ} \mathrm{C}$ for $12 \mathrm{~h}$, then the reaction mixture was worked up in the usual way to give a residue. The residue was chromatographed on a silica gel column (EtOAc : hexane $=2: 1)$ to give 9 as an amorphous powder $(9 \mathrm{mg}) .9,[\alpha]_{\mathrm{D}}^{22}+12.6^{\circ}(c=0.2, \mathrm{MeOH})$. EI-MS $m / z$ (rel. int.): $586[\mathrm{M}]^{+}(0.1), 571\left[\mathrm{M}-\mathrm{CH}_{3}\right]^{+}(0.2), 526\left[\mathrm{M}-\mathrm{CH}_{3} \mathrm{COOH}\right]^{+}$(2), 484 (2.5), 466 $\left[\mathrm{M}-2 \times \mathrm{CH}_{3} \mathrm{COOH}\right]^{+}(5), 451$ (1), 424 (2), 286 (4.5), 244 (4), 140 (22.5), 98 (13.7), 43 [CH$\left._{3} \mathrm{CO}\right]^{+}$(100). HR-MS: 
Calcd for $\mathrm{C}_{26} \mathrm{H}_{35} \mathrm{O}_{14}\left(\mathrm{M}-\mathrm{CH}_{3}\right)$ : 571.2026. Found: 571.2035.

Hydrolysis, Followed by Acetylation of 7 - A solution of $7(5 \mathrm{mg})$ in $0.1 \mathrm{M} \mathrm{NaOEt}-\mathrm{EtOH}(1 \mathrm{ml})$ was stirred at room temperature for $12 \mathrm{~h}$, then the reaction mixture was neutralized with $\mathrm{AcOH}$ and evaporated to give a residue, which was purified by using silica gel column chromatography with EtOAc-MeOH $(5: 1)$ to give a hexahydroxy product. This product was acetylated by using $\mathrm{Ac}_{2} \mathrm{O}(0.5 \mathrm{ml})$ and pyridine $(0.5 \mathrm{ml})$ at $70^{\circ} \mathrm{C}$ for $12 \mathrm{~h}$, and worked up in the usual way to give a residue, which was purified by using silica gel column chromatography with EtOAc-hexane (2:1) to give 9 as an amorphous powder $(3 \mathrm{mg}) .9,[\alpha]_{\mathrm{D}}^{22}+10.9^{\circ}(c=0.2, \mathrm{MeOH}), \mathrm{EI}-\mathrm{MS} m / z$ (rel. int.): $586[\mathrm{M}]^{+}(1)$, $571\left[\mathrm{M}-\mathrm{CH}_{3}\right]^{+}(9), 526\left[\mathrm{M}-\mathrm{CH}_{3} \mathrm{COOH}\right]^{+}(17), 511(12), 484(10), 466\left[\mathrm{M}-2 \times \mathrm{CH}_{3} \mathrm{COOH}\right]^{+}$(19), 424 (6), 409 (7), $406\left[\mathrm{M}-3 \times \mathrm{CH}_{3} \mathrm{COOH}\right]^{+}(5), 165$ (17), 140 (90), 98 (59), $43\left[\mathrm{CH}_{3} \mathrm{CO}\right]^{+}$(100). HR-MS: Calcd for $\mathrm{C}_{27} \mathrm{H}_{38} \mathrm{O}_{14}$ : 586.2262. Found: 586.2241 .

Acetylation of $7-\mathrm{A}$ solution of $7(11 \mathrm{mg})$ in $\mathrm{Ac}_{2} \mathrm{O}(0.5 \mathrm{ml})$ and pyridine $(0.5 \mathrm{ml})$ was stirred at room temperature for $48 \mathrm{~h}$, then the reaction mixture was worked up in the usual way to give amorphous power $(12 \mathrm{mg}) .8$, ${ }^{1} \mathrm{H}-\mathrm{NMR}\left(\mathrm{CDCl}_{3}\right) \delta: 1.52,1.57,1.80\left(\right.$ each $\left.3 \mathrm{H}, \mathrm{s}, \mathrm{CH}_{3}\right), 1.53,2.09,2.15,2.42\left(\right.$ each $\left.3 \mathrm{H}, \mathrm{s}, \mathrm{COCH}_{3}\right), 1.97(1 \mathrm{H}, \mathrm{dd}, J=$ $15.2,2.9 \mathrm{~Hz}, \mathrm{H}-3), 2.71(1 \mathrm{H}, \mathrm{d}, J=3.3 \mathrm{~Hz}, \mathrm{H}-7), 2.78(1 \mathrm{H}, \mathrm{s}, 4-\mathrm{OH}), 4.74,4.95$ (each $\left.1 \mathrm{H}, \mathrm{ABq}, J=13.4 \mathrm{~Hz}, \mathrm{H}_{2}-15\right)$, $5.37(1 \mathrm{H}, \mathrm{m}, \mathrm{H}-2), 5.54(1 \mathrm{H}, \mathrm{d}, 3.4 \mathrm{~Hz}, \mathrm{H}-1), 5.83(1 \mathrm{H}, \mathrm{dd}, J=9.8,3.3 \mathrm{~Hz}, \mathrm{H}-8), 6.25(1 \mathrm{H}, \mathrm{d}, J=9.8 \mathrm{~Hz}, \mathrm{H}-9), 6.68$ (1 H, s, H-6), $7.33-7.91\left(10 \mathrm{H}\right.$, aromatic H). EI-MS m/z (rel. int.): $695\left[\mathrm{M}-\mathrm{CH}_{3}\right]^{+}$(5), $650\left[\mathrm{M}-\mathrm{CH}_{3} \mathrm{COOH}\right]^{+}(5)$, $590\left[\mathrm{M}-2 \times \mathrm{CH}_{3} \mathrm{COOH}\right]^{+}(15), 588\left[\mathrm{M}-\mathrm{C}_{6} \mathrm{H}_{5} \mathrm{COOH}\right]^{+}(9.5), 202(70), 105\left[\mathrm{C}_{6} \mathrm{H}_{5} \mathrm{CO}\right]^{+}(64), 43\left[\mathrm{CH}_{3} \mathrm{CO}\right]^{+}(100)$. HR-MS: Calcd for $\mathrm{C}_{36} \mathrm{H}_{39} \mathrm{O}_{14}\left(\mathrm{M}-\mathrm{CH}_{3}\right)$ : 695.2340. Found: 695.2334.

Partial Hydrolysis of $7-\mathrm{A}$ solution of $7(20 \mathrm{mg})$ in $0.02 \mathrm{M} \mathrm{K}_{2} \mathrm{CO}_{3}-\mathrm{MeOH}(1.5 \mathrm{ml})$ was stirred at room temperature for $12 \mathrm{~h}$, then the reaction mixture was neutralized with $1 \% \mathrm{HCl}$ and evaporated in vacuo to give a residue, which was purified by using silica gel column chromatography with EtOAc-hexane $(1: 1)$ to give 12 as an amorphous powder ( $2 \mathrm{mg})$. 12, ${ }^{1} \mathrm{H}$-NMR: see Table II.

$\mathrm{NaBH}_{4}$ Reduction of 11 - A solution of $11(90 \mathrm{mg})$ and $\mathrm{NaBH}_{4}(20 \mathrm{mg})$ in $\mathrm{MeOH}(4 \mathrm{ml})$ was stirred at room temperature for $40 \mathrm{~min}$, then the reaction mixture was worked up in the usual way to give a residue, which was chromatographed on a silica gel column (hexane: EtOAc $=1: 1)$ to give $12(34 \mathrm{mg})$ and $13(7 \mathrm{mg}) .13,{ }^{1} \mathrm{H}-\mathrm{NMR}$ $\left(\mathrm{CDCl}_{3}\right) \delta: 1.48,1.56,1.75\left(\right.$ each $\left.3 \mathrm{H}, \mathrm{s},-\mathrm{CH}_{3}\right), 1.45,2.09,2.14,2.30\left(\right.$ each $\left.3 \mathrm{H}, \mathrm{s}, \mathrm{COCH}_{3}\right), 1.94(1 \mathrm{H}, \mathrm{dd}, J=15.3$, $\left.2.8 \mathrm{~Hz}, \mathrm{H}_{\mathrm{ax}}-3\right), 2.47(1 \mathrm{H}, \mathrm{d}, J=3.2 \mathrm{~Hz}, \mathrm{H}-7), 2.80(1 \mathrm{H}, \mathrm{s}, 4-\mathrm{OH}), 4.45(1 \mathrm{H}, \mathrm{dd}, J=9.3,3.2 \mathrm{~Hz}, \mathrm{H}-8), 4.70,4.96$ (each $\left.1 \mathrm{H}, \mathrm{ABq}, J=13.4 \mathrm{~Hz}, \mathrm{H}_{2}-15\right), 5.34(1 \mathrm{H}, \mathrm{ddd}, J=3.2,3.2,2.8 \mathrm{~Hz}, \mathrm{H}-2), 5.46(1 \mathrm{H}, \mathrm{d}, J=3.2 \mathrm{~Hz}, \mathrm{H}-1), 5.87(1 \mathrm{H}, \mathrm{d}, J=$ $9.3 \mathrm{~Hz}, \mathrm{H}-9), 6.37(1 \mathrm{H}, \mathrm{s}, \mathrm{H}-6), 7.47-7.98(5 \mathrm{H}$, aromatic $\mathrm{H})$. Anal. Calcd for $\mathrm{C}_{30} \mathrm{H}_{38} \mathrm{O}_{13}: \mathrm{C}, 59.40 ; \mathrm{H}, 6.31$. Found: C, $59.54 ; \mathrm{H}, 6.14$.

Reduction of $14-A$ solution of $14(12 \mathrm{mg})$ and $\mathrm{NaBH}_{4}(10 \mathrm{mg})$ in $\mathrm{MeOH}(2.5 \mathrm{ml})$ was stirred at room temperature for $1.5 \mathrm{~h}$, then the reaction mixture was worked up in the usual way to give a residue, which was purified by using preparative TLC with $\mathrm{CHCl}_{3}-\mathrm{MeOH}(97: 3)$ to give $15(1 \mathrm{mg})$ and $16(5 \mathrm{mg}) .15,{ }^{1} \mathrm{H}-\mathrm{NMR}\left(\mathrm{CDCl}_{3}\right) \delta: 1.26$, $1.52,1.79\left(\right.$ each $\left.3 \mathrm{H}, \mathrm{s}, \mathrm{CH}_{3}\right), 2.08,2.16,2.34\left(\right.$ each $\left.3 \mathrm{H}, \mathrm{s}, \mathrm{COCH}_{3}\right), 2.49(1 \mathrm{H}, \mathrm{d}, J=3.2 \mathrm{~Hz}, \mathrm{H}-7), 2.84(1 \mathrm{H}, \mathrm{s}, 4-\mathrm{OH})$, $4.48(1 \mathrm{H}$, br d, $J=9.8 \mathrm{~Hz}, \mathrm{H}-8), 4.88,5.14$ (each $\left.1 \mathrm{H}, \mathrm{ABq}, J=13.3 \mathrm{~Hz}, \mathrm{H}_{2}-15\right), 5.43(1 \mathrm{H}, \mathrm{ddd}, J=3.4,3.4,3.4 \mathrm{~Hz}, \mathrm{H}-$ 2), $5.79(1 \mathrm{H}, \mathrm{d}, J=3.4 \mathrm{~Hz}, \mathrm{H}-1), 5.98(1 \mathrm{H}, \mathrm{d}, J=9.8 \mathrm{~Hz}, \mathrm{H}-9), 6.42(1 \mathrm{H}, \mathrm{s}, \mathrm{H}-6), 6.85-7.52$ (10H, aromatic H). EI-MS $m / z$ (rel. int.): $653\left[\mathrm{M}-\mathrm{CH}_{3}\right]^{+}$(1), $608\left[\mathrm{M}-\mathrm{CH}_{3} \mathrm{COOH}\right]^{+}(0.5), 548\left[\mathrm{M}-2 \times \mathrm{CH}_{3} \mathrm{COOH}\right]^{+}$(2.5), 546 $\left[\mathrm{M}-\mathrm{C}_{6} \mathrm{H}_{5} \mathrm{COOH}\right]^{+}(0.2), 486\left[\mathrm{M}-\mathrm{CH}_{3} \mathrm{COOH}-\mathrm{C}_{6} \mathrm{H}_{5} \mathrm{COOH}\right]^{+}(1), 105\left[\mathrm{C}_{6} \mathrm{H}_{5} \mathrm{CO}\right]^{+}(100), 43\left[\mathrm{CH}_{3} \mathrm{CO}\right]^{+}(43) . \mathrm{HR}-$ MS: Calcd for $\mathrm{C}_{34} \mathrm{H}_{37} \mathrm{O}_{13}\left(\mathrm{M}-\mathrm{CH}_{3}\right)$ : 653.2234. Found: 653.2248. 16, ${ }^{1} \mathrm{H}-\mathrm{NMR}\left(\mathrm{CDCl}_{3}\right) \delta: 1.65,1.78,1.80(\mathrm{each} 3 \mathrm{H}$, $\left.\mathrm{s},-\mathrm{CH}_{3}\right), 2.09,2.28\left(\right.$ each $\left.3 \mathrm{H}, \mathrm{s}, \mathrm{COCH}_{3}\right), 2.61(1 \mathrm{H}, \mathrm{d}, J=3.4 \mathrm{~Hz}, \mathrm{H}-7), 3.18(1 \mathrm{H}, \mathrm{s}, 4-\mathrm{OH}), 4.35(1 \mathrm{H}, \mathrm{brd}, J=9.5 \mathrm{~Hz}$, $\mathrm{H}-8), 4.98\left(2 \mathrm{H}, \mathrm{s}, \mathrm{H}_{2}-15\right), 5.07(1 \mathrm{H}, \mathrm{d}, J=5.3 \mathrm{~Hz}, 6-\mathrm{OH}), 5.25(1 \mathrm{H}, \mathrm{d}, J=5.3 \mathrm{~Hz}, \mathrm{H}-6), 5.45(1 \mathrm{H}, \mathrm{m}, \mathrm{H}-2), 5.79(1 \mathrm{H}, \mathrm{d}$, $J=3.7 \mathrm{~Hz}, \mathrm{H}-1), 6.00(1 \mathrm{H}, \mathrm{d}, J=9.5 \mathrm{~Hz}, \mathrm{H}-9), 6.85-7.53(10 \mathrm{H}$, aromatic $\mathrm{H})$.

Acetylation of $16-A$ solution of $16(5 \mathrm{mg})$ in $\mathrm{Ac}_{2} \mathrm{O}(0.5 \mathrm{ml})$ and pyridine $(0.5 \mathrm{ml})$ was stirred at $70^{\circ} \mathrm{C}$ for $12 \mathrm{~h}$, then the reaction mixture was worked up in the usual way to give a residue, which was purified by using silica gel column chromatography with $\mathrm{CHCl}_{3}$-acetone $(49: 1)$ to give $\mathbf{1 0}$ as an amorphous powder $(4.5 \mathrm{mg}) .10,[\alpha]_{\mathrm{D}}^{22}+20.1^{\circ}$ $(c=0.15, \mathrm{MeOH})$.

Hydrolysis Followed by Acetylation of 13 - A solution of $13(8 \mathrm{mg})$ in $0.1 \mathrm{M} \mathrm{NaOH}-\mathrm{EtOH}(1 \mathrm{ml})$ was stirred at room temperature for $10 \mathrm{~h}$, then the reaction mixture was evaporated in vacuo to give a residue, which was chromatographed on a silica gel column (EtOAc: $\mathrm{MeOH}=5: 1)$ to give a hexahydroxy derivative $(4.2 \mathrm{mg})$. This product was acetylated by using $\mathrm{Ac}_{2} \mathrm{O}$-pyridine at $70^{\circ} \mathrm{C}$ for $18 \mathrm{~h}$, followed by usual work-up to give a residue, which was purified by using silica gel column chromatography (hexane : EtOAc $=3: 2)$ to give $9(4 \mathrm{mg}),[\alpha]_{\mathrm{D}}^{22}+13.5^{\circ}(c=$ $0.20, \mathrm{MeOH})$.

Hydrolysis Followed by Acetylation of 10 -Compound $10(6 \mathrm{mg})$ was treated in the same way as described above to give 9 as an amorphous powder $(4 \mathrm{mg}),[\alpha]_{\mathrm{D}}^{22}+12.1^{\circ}(c=0.2, \mathrm{MeOH})$.

Acknowledgements We thank Prof. Y. Asakawa of Tokushima Bunri University for CD measurements and the staff of the Analytical Center of this Faculty for measurements of NMR, mass spectrum, and elemental analysis.

\section{References}

1) G. Juling, Y. Shixiang, W. Xichun, X. Shixi, and L. Deda, Chin. Med. J., 94, 405 (1981). 
2) S. M. Kupchan, W. A. Court, R. G. Dailey, C. J. Gilmore, Jr., and R. F. Bryan, J. Am. Chem. Soc., 94, 7194 (1972).

3) J. P. Kutney, M. H. Beale, P. J. Salisbury, R. D. Sindelar, K. L. Stuart, B. R. Worth, P. M. Townsley, W. T. Chalmers, D. J. Donnelly, K. Nilsson, and G. G. Jacoli, Heterocycles, 14, 1465 (1980); J. P. Kutney, G. M. Hewitt, T. Kurihara, P. J. Salisbury, R. D. Sindelar, K. L. Sturt, P. M. Townsley, and W. T. Chalmers, Can. J. Chem., 59, 2677 (1981).

4) M. Beroza, J. Am. Chem. Soc., 75, 2136 (1953).

5) H. Hori, G. Pang, K. Hariyama, Y. Iitake, and S. Inayama, Chem. Pharm. Bull., 35, 2125, 4683 (1987).

6) Y. Takaishi, K. Ujita, K. Nakano, K. Murakami, and T. Tomimatsu, Phytochemistry, 26, 2325 (1987); Y. Takaishi, K. Ujita, K. Kida, M. Shibuya, and T. Tomimatsu, ibid., 26, 2581 (1987).

7) W. Vichnewski, J. S. Prasad, and W. Herz, Phytochemistry, 23, 1655 (1984).

8) M. J. Begley, L. Crombie, R. A. Fleming, D. A. Whiting, Z. Roza, M. Kelenyi, J. Hohmann, and K. Szendrei, J. Chem. Soc., Perkin Trans. 1, 1986, 535; R. Bruning and H. Wagner, Phytochemistry, 17, 1821 (1978).

9) S. M. Kupchan, R. M. Smith, and R. F. Bryan, J. Am. Chem. Soc., 92, 6667 (1970); H. Wagner, E. Heckel, and J. Sonnenbichler, Tetrahedron, 31, 1949 (1975).

10) N. Harada and K. Nakanishi, J. Am. Chem. Soc., 91, 3989 (1969). 